Published in Ethnic \& Racial Studies 38(10): 1671-1689.

https://www.tandfonline.com/doi/abs/10.1080/01419870.2015.1015584

\title{
Christian Nationalism and White Racial Boundaries: Examining Whites' Opposition to Interracial Marriage
}

\author{
Samuel L. Perry \\ University of Oklahoma \\ Andrew L. Whitehead \\ Clemson University
}

\begin{abstract}
How does the convergence of national and religious identities potentially fortify white racial boundaries in the United States? Focusing on openness to racial exogamy as an indicator of racial boundaries, we examine the link between Christian nationalism and white Americans' views toward their hypothetical daughter marrying an African American, Latino, or Asian. Drawing on theoretical insights from social identity complexity theory, we argue that the convergence of religious and national identities serves to reinforce in-group boundaries, thereby fortifying notions of white purity, and consequently, strengthening whites' discomfort with potential race-mixing in marriage. Multivariate analyses of national survey data demonstrate that Christian nationalism is strongly associated with an increase in white Americans' discomfort with their daughter marrying any racial minority, and particularly African Americans. We demonstrate how the convergence of religious and national identities in Christian nationalism influences whites' regulating of racial boundaries (evidenced in intermarriage attitudes) above and beyond the independent effects of political conservatism or religious exclusivism.
\end{abstract}

Key words: Christian nationalism, interracial marriage, religion, racial boundaries, social identity 


\section{Introduction}

Within the United States, the boundaries of whiteness have traditionally included a variety of symbolic and behavioral dimensions that represent criteria for inclusion, both in the more proximate (family, friends, neighbors) and distal (institutions, citizenship) sense. Beyond perceived phenotypical differences, these symbolic criteria have included language, class, gender, economic ideology, sexual orientation, and perhaps most prominently, national origins

and religion (Edgell and Tranby 2010; Gordon 1964; Lamont and Molnar 2000; Omi and Winant 1994). Historically, white Americans have been reluctant to relax the boundaries of whiteness and extend in-group privileges to persons outside of the white-majority national (AngloEuropean) or religious (Protestant) heritage (Allport 1954; Bonilla-Silva 1999 Edgell et al. 2006; Gordon 1964; Lee and Bean 2010). Although research has shown that white Americans who identify as more politically-traditionalist are relatively more likely to maintain rigid racial boundaries, as are whites who identify with more-exclusivist, sectarian religious groups (Edgell and Tranby 2010; Emerson and Smith 2000; Lamont and Molnar 2000), little empirical work as focused on the ways in which social identities that blur the lines between national and religious group membership may also fortify white racial boundaries in the U.S. in ways that are above and beyond the independent influences of political conservatism or religious exclusivism.

Following the election of George W. Bush in 2000 and culminating in the Tea Party movement since 2009, scholars have called attention to what they consider to be a resurgence of a conservative strain of national-religious identity or 'Christian nationalism' (Aho 2013; Goldberg 2006; Gorski 2009, 2010; McDaniel et al. 2011), defined as a 'blending of Christian and patriotic narratives and iconography that blurs or erases the line between religious and political community and identity' (Gorski 2009, 91). Simply put, Christian nationalists envision 
'the boundaries of the religious and political communities to be as coterminous as possible' (Gorski 2010, 7). Scholars point out that Christian nationalist ideology has historically had highly racialized and imperialist underpinnings; and some theorize that a resurgence of Christian nationalism in the public sphere will likely serve to buttress notions of white purity and systemic non-white exclusion in American social life (Aho 2013; Barkun 1994; Goldberg 2006). Despite its plausibility, little empirical research exists to substantiate this theory or to flesh out the potential mechanisms at work in this relationship.

Focusing on white Americans' openness to interracial marriage as a particularly salient indicator of racial boundaries (Allport 1954; Childs 2005; Gordon 1964; Lee and Bean 2010; Pascoe 2009; Qian and Lichter 2007) and drawing on theoretical insights from social identity complexity theory (Roccas and Brewer 2002; Schmid et al. 2009), in this article, we analyze national-level survey data to examine the extent to which Christian nationalism-representing a convergence of national and religious identities - potentially fortifies whites' unwillingness to relax the boundaries of whiteness, as evidenced by their reported discomfort with a hypothetical daughter marrying an African American, Asian, or Latino. The results from this research extend our understanding of the intersections of social identities, persistent racial exclusion, and contemporary national politics by highlighting a potential mechanism linking revitalized efforts to 'preserve' or 'recover' America's 'Christian heritage' on the Religious Right with covertlyracist intent, and ultimately contributing to the fortification of racial boundaries.

\section{Background and Framework}

National Religious Identity and White Supremacy in the United States

Gorski $(2009,2010)$ traces the development and ideological content of Christian nationalism in the United States to two principal sources: ethno-nationalism and the Hebrew 
Bible. Christian nationalists read Old Testament passages about the chosen-ness of the Israelites and God's demand for their blood-purity through sacrifice and through marital-endogamy not as a metaphor of covenant, but more literally as requiring ethnic separation and the racial purity of the chosen people. Despite the historically ethnicized content of Christian nationalism, Gorski (2010) theorizes that, following the Holocaust and the Civil Rights movement, the explicitly racialist versions of Christian nationalism were undermined and weakened.

Other writers, however, maintain that Christian nationalism, applied to contemporary white America, implies the same desire for white racial purity and exclusivity though in a more covert form. Aho (2013) and Goldberg (2006), for example, argue that Christian nationalist ideals - e.g., support for policies expanding religion's role in government, discouraging debt, and enforcing biblical morality and work ethic — help constitute the belief structure undergirding contemporary neoliberal ideology which staunchly opposes both welfare aid to poor minority families and race-based affirmative action policies in education and employment. Aho (2013) also demonstrates how contemporary Christian nationalists engage in a revisionist history of race-relations in America's past, expressing ambivalence about the slavery of African Americans, and even emphasizing the 'benefits' that accrued to blacks because of their enslavement (for example, see Barton 2011).

Scholars also draw a connection between contemporary Christian nationalism and xenophobic and racist opposition to immigration. At the ideological level, because Christian nationalists believe America's 'Christian heritage' should be defended, they tend to oppose the immigration of non-Christians (e.g., Muslims), who also tend to be non-white (Aho 2013). Directly testing for a link between Christian nationalism and anti-immigration sentiment, McDaniel et al. (2011) demonstrate that Christian nationalist ideology is a strong predictor of 
antagonism toward immigrants, and that evangelical Protestantism only predicts anti-immigrant views when Christian nationalism is not considered. The authors, however, do not specify how the effect of Christian nationalism on public opinion toward immigrants was potentially moderated by the ethnicity of the immigrant in question (e.g., Asian, Latino, African, etc.). Moreover, because many non-white ethnic immigrants are non-Christian as well, it is difficult to discern the extent to which this observed link between Christian nationalism and anti-immigrant sentiments is due to ethnic prejudice or religious prejudice primarily. The current study resolves these issues by focusing on whites' openness toward intermarriage with African Americans, Latinos, and Asians, as well as controlling for religious exclusivism in multivariate models.

\section{White Opposition to Racial Endogamy as an Indicator of Racial Boundaries}

Despite the prevalence of white/non-white sexuality in American history, notions of white biological and cultural supremacy historically inclined whites to oppose race-mixing as a threat to white racial purity and, ultimately, white dominance (Pascoe 2009). This fear of racemixing provoked whites to establish and enforce racial segregation in residence, work, education, social and religious life, and most importantly in marriage relationships (Childs 2005; Pascoe 2009; Root 2001; Rosenfeld 2007; Spickard 1989). In her landmark historical study of anti-miscegenation law, Pascoe $(2009,6)$ argues, 'Miscegenation law...was not just one of the various forms of segregation practiced between 1880 and 1930 but the foundation for the larger racial projects of white supremacy and white purity.' Thus, race scholars have long argued that greater approval of racial exogamy among whites 'would symbolize the abolition of prejudice' (Allport 1954, 377), serving as a leading indicator that racial boundaries were abating and whites were granting full acceptance to minorities (Allport 1954; Gordon 1964; Lee and Bean 2010). Additionally, whites' openness to intermarriage with particular minority groups has also served 
as an indicator of racial hierarchy between groups, with whites historically being more averse to intermarriage with blacks, compared to Asians or Latinos (Author 2013a, 2013b; Herman and Campbell 2012; Rosenfeld 2007; Spickard 1989). Building on this research, understanding what social and ideological factors shape whites' views toward interracial marriage with blacks, Latinos, and Asians provides insight into what factors may contribute to the weakening, or, conversely, the fortification of white racial boundaries, and whether these boundaries are closed to certain groups more than others.

Previous research examining what factors tend to predict opposition toward racial exogamy finds that whites who disapprove of interracial marriage tend to be older, male, politically conservative, live in the American South, have racially homogenous backgrounds (neighborhoods, workplaces, schools, congregations), racially intolerant families, lower incomes, tend to be less educated, come from less educated families, are generally more religious (mostly in terms of church attendance) and more theologically conservative (Author 2013a, 2013b, 2014; Golebiowska 2007; Herman and Campbell 2012; Johnson and Jacobson 2005; Rosenfeld 2007; Wilson and Jacobson 1995; Yancey 1999, 2001). In general, this research suggests that interracial marriage tends to be opposed by whites who are more traditionalist in other areas. This leads us to consider the role of religion — often an indicator of not only more traditionalist identities and beliefs but also robust in-group cultural boundaries that may be extended and projected onto national boundaries—on whites' support for interracial marriage.

\section{Christian Nationalism, Racial Boundaries, and Whites' Views toward Racial Exogamy}

Most studies that test religion's influence on intermarriage attitudes find that whites who are more religiously devout in terms of church attendance (Golebiowska 2007; Herman and Campbell 2012; Johnson and Jacobson 2005; Yancey 1999, 2001), religious practice in general 
(Herman and Campbell 2012; but see Author 2013a, 2014), or in depth of religious commitment (Wilson and Jacobson 1995) tend to be less open to racial exogamy. Scholars have also reported that white conservative Protestants or evangelicals are more likely to express disapproval of (often black-white) interracial marriage, relative to Mainline Protestants, Catholics, or the religiously unaffiliated (Putnam and Campbell 2010; Spickard 1989; Wilson and Jacobson 1995). More recently, the author (2014) reported that whites who express a greater desire to pass on religious heritage are less likely to support the idea of their daughters marrying interracially with any minority groups. This finding suggests that, for white Americans, religious identity has an ethnic component in that whites who desire their descendants to carry their religious heritage implicitly expect that those descendants will be white. This finding also suggests that other aspects of religious identity may influence whites' support of racial exogamy.

While no studies have explicitly sought to link Christian nationalism with white opposition to racial exogamy, several authors theorize that such a connection likely exists. In her study of Christian nationalism, Goldberg (2006) cites research indicating that almost fifty percent of white conservative Christians would disapprove of their child marrying a black person, compared to about 22 percent of white Americans in general. Yancey (2007) found that white American online daters who were both frequent churchgoers and politically conservative (which he suggests may be a proxy for the Religious Right) were less willing to date non-whites. Yancey theorizes that the particular conservative religious ideology of the Religious Right may support notions of racial purity in romantic and family relationships. Lastly, examining the criteria for cultural membership among Americans, Edgell and Tranby (2011) found that 'cultural preservationists,' those who seek to defend America's unified, white Christian culture, are more likely than either 'optimistic pluralists' or 'critics of multiculturalism' to disapprove if 
their child wanted to marry 'someone different from him/herself' (measured on a scale across eight different categories).

Based on these findings and contemporary theories linking Christian nationalism with the fortification of white racial boundaries, we predict that as support for Christian nationalism increases, white Americans will be less comfortable with the idea of their children marrying interracially. The theoretical concept of social identity complexity allows us to further highlight the mechanisms at work in the relationship between Christian nationalism and racial boundaries.

\section{Christian Nationalism and Social Identity Complexity Theory}

Social identity complexity (SIC) refers to individuals' subjective representation of the interrelationships among their multiple group identities (Roccas and Brewer 2002). Individuals with high SIC see their in-groups as mostly distinct with cross-cutting memberships. Those with low SIC perceive their in-groups as mostly overlapping and convergent (Brewer and Pierce 2005). As Roccas and Brewer $(2002,95)$ point out, even if an individual objectively knows that their in-groups do not share a high overlapping membership (not all Americans are Christians), she can 'still subjectively represent her identities as highly overlapping' ( $m y$ type of Americans are Christians). In instances of high perceived overlap in group memberships the different ingroups actually come to be conceived of as a single convergent social identity (Brewer,

Gonsalkorale, and van Dommelen 2013; Brewer and Pierce 2005). Christian nationalists are one example of a single convergent social identity arising out of the perception of a high degree of overlap between three identities, in this case, Christian, American, and (for most Christian nationalists) white.

When individuals perceive a large degree of overlap between their group memberships, they are more likely to exaggerate the homogeneity of the group and to erect strict group 
boundaries delineating between those in the group from those outside (Roccas and Brewer 2002). Furthermore, low SIC individuals are more likely to perceive threats to their in-group and their single convergent social identity because it is in many cases their most important social identity (McDaniel et al. 2011; Roccas and Brewer 2002; Schmid et al. 2009). A number of studies demonstrate that variation in SIC is associated with attitudes toward out-groups (Brewer and Pierce 2005; Roccas and Brewer 2002; Schmid et al. 2009). Regarding attitudes toward different racial/ethnic categories, individuals with low SIC tend to be more intolerant of racial/ethnic outgroups while individuals with higher SIC tend to be more accepting (Brewer et al. 2013; Brewer and Pierce 2005; Miller, Brewer, and Arbuckle 2009).

Because Christian nationalists maintain a single convergent social identity marked by low SIC which is accompanied by a perception that an out-group member on one dimension (e.g., racial identity) is an out-group member on all other dimensions (e.g., religious and national identity), they will be much more likely to maintain strict boundaries between their in-group (Christian, American, predominantly-white) and racial out-groups (McDaniel et al. 2011). In other words, the low SIC of white Christian nationalists would incline them to strongly favor, not only government policies and practices that reinforce their shared religio-national identity of 'Christian-Americans,' but also salient racial boundaries in social relationships that buttress notions of white racial purity.

Based on these insights from empirical work on Christian nationalism, whites' views toward interracial marriage, and SIC theory, we expect that, net of other effects, white Americans who more strongly adhere to Christian nationalism will be less comfortable with their children marrying an African American, Latino, or Asian. Additionally, building on previous research finding that white Americans tend to be more opposed to interracial marriage with 
African Americans compared to Latinos or Asians, we expect that: Christian nationalism's influence on the strengthening of white racial boundaries will be more pronounced regarding African Americans, being perceived as a more distinct and stigmatized out-group for white Americans, relative to Latinos and Asians.

\section{Data and Method}

We test the above hypothesis using data from wave 2 of the Baylor Religion Survey (BRS), which was fielded in 2007. The BRS was designed with a goal to comprehensively assess the religious attitudes, beliefs, and behaviors of American adults. Although the majority of BRS measures inquire about respondents' religious lives, the 2007 BRS also included a module containing dozens of questions inquiring about the racial composition of respondents' workplaces, neighborhoods, friendship networks, and congregations; their attitudes toward interracial marital relationships; and whether they personally had ever engaged in interracial dating or romance. This combination of question tapping respondents' religio-political views and views toward racial issues is unavailable in any other survey.

Survey data were collected by the Gallup Organization, with a final $N$ of 1,648 cases. The BRS was drawn from a national random sample of U.S. adults with telephones obtained through random digit dialing. In total, 3,500 potential respondents were contacted and asked if they would be willing to complete a mailed questionnaire. One thousand of these 3,500 were also given a brief phone interview to check for systematic bias in the types of people who refused to participate. A total of 2,460 questionnaires were mailed out to those who agreed to participate, with 1,648 questionnaires returned for a response rate of 47.1 percent $(1,648 / 3,500)$. Demographic results from wave 2 of the BRS compare favorably to demographic results from other national surveys like the General Social Survey. To correct for missing data, we utilized a 
multiple imputation (MI) procedure (Rubin 1996). All results use the MI dataset. For a detailed description of data collection and sampling procedures, see Bader, Mencken, and Froese (2007).

\section{Opposition to Interracial Marriage}

The dependent variable for this study is whites' reported level of discomfort with a hypothetical daughter marrying someone from a specific minority group. The BRS asked respondents, 'How comfortable would you be if a daughter of yours married someone who is [black or African American, Hispanic or Latino, Asian]?' The framing of this question is an improvement over survey questions that ask white respondents about whether they personally would consider marrying someone of another race, since some respondents might explain that they simply are not attracted to blacks, Latinos, or Asians, and thus, their unwillingness to outmarry may not be due to overt racial prejudice. Asking respondents how they would feel about their daughter out-marrying is a better way to gauge whether they would disapprove of the union due to prejudicial attitudes about other racial groups. Possible responses to this question include: (1) 'not at all comfortable,' (2) 'somewhat comfortable,' and (3) 'very comfortable.' For our analyses, we dichotomized this measure into $1=$ 'not at all comfortable' and $0=$ 'somewhat/very comfortable. ${ }^{1}$ Respondents with a 1 for this measure are therefore understood to unequivocally disapprove of interracial marriage to a member of the specified minority group. ${ }^{2}$

\section{Christian Nationalism Measures}

Our focal independent variable is white respondents' adherence to Christian nationalism.

To measure this concept, we construct an index utilizing six level-of-agreement statements, which were as follows. (Christian Nation) 'The federal government should declare the United

\footnotetext{
${ }^{1}$ Initial analyses indicated that the three-value coding of the dependent variable violated the proportional odds assumption and thus we were unable to use ordinal regression.

${ }^{2}$ Regression analyses were also run with $1=$ 'very comfortable' and $0=$ 'somewhat/not at all comfortable,' and results were substantively the same (available upon request).
} 
States a Christian Nation.' (Christian Values) 'The federal government should advocate Christian values.' (Religious Symbols) 'The federal government should allow the display of religious symbols in public spaces.' (School Prayer) 'The federal government should allow prayer in public schools.' (God's Plan) 'The success of the United States is part of God's plan.' And (Church/State) 'The federal government should enforce a strict separation of church and state' (reverse-coded). Responses ranged from (1) Strongly Disagree to (5) Strongly Agree. The Cronbach's alpha coefficient for these measures was .89 indicating high reliability.

Prior research utilizing social identity complexity operationalized the concept by asking respondents to identify various groups of which they consider themselves a part (Brewer et al. 2009; Brewer and Pierce 2005; Miller et al. 2009; Roccas and Brewer 2002; Schmid et al. 2009). McDaniel and colleagues (2011) extended this work to measure Christian nationalism as a social identity by constructing an index using responses from six statements similar to those found in the 2007 BRS. We construct this measure of Christian nationalism and social identity complexity by following McDaniel et al.'s (2011) work in this analysis. We also understand that this measure does not assess the totality of someone's social identity and that is not our goal. Rather, we aim to discover if one aspect of their identity, be it more or less complex, can influence their views on an important social issue like race.

\section{Controls}

Multivariate analyses include a host of socio-demographic controls. Age is measured in years from 18 to 96 . We include dummy variables for gender (female $=1)$, marital status $($ married $=1)$, children $($ any children $=1)$, and region $($ South $=0$, East $=1$, West $=1$, Midwest $=$ 1). Education is measured in attainment categories from (1) $8^{\text {th }}$ grade or less to (7) postgraduate work/degree. Political ideology is measured from (1) extremely liberal to (7) extremely 
conservative. To control for religious factors, the analyses include measures for religious tradition, beliefs about the Bible, religious practice, and the respondents' desire for their child to marry within their religion. Religious tradition is measured with seven broad categories following Steensland et al. (2000): evangelical, mainline Protestant, Catholic, Black Protestant, Jewish, Other, and Unaffiliated. Evangelicals serve as the reference category. We also control for whether respondents are biblical literalists (biblical literalism $=1$, all other views of the Bible $=$ 0 ). In order to gauge various dimensions of religious behavior, we constructed a religious practice scale using three BRS questions concerning respondents' frequency of religious service attendance, sacred text reading, and prayer. For frequency of religious service attendance and sacred text reading, respondents could indicate (1) never to (9) several times a week. For prayer frequency, respondents chose options from (1) never to (6) several times a day. These measures were standardized into $\mathrm{Z}$ scores and summed in order to create the religious practice scale ( $\alpha=$ .83). Lastly, the BRS asks respondents how important it is to them that their hypothetical child marries someone who shares the parent's religion. We include this measure to control for respondents' desire for religious endogamy (unimportant $=1$, important $=0$ ). Lastly, multivariate analyses controlled for whether respondents had close friends who were [black, Latino, or Asian]. Respondents who did not have any [black, Latino, or Asian] friends are coded 1.

\section{[TABLE 1 ABOUT HERE]}

\section{Findings}

Table 1 presents descriptive statistics for all variables in multivariate models. Consistent with previous research, for white Americans, the prospect of intermarriage with African Americans seems to be somewhat more discomfiting than marriage to Latinos or Asians. While only 20 percent of whites are 'not at all comfortable' with their hypothetical daughters marrying 
a Latino or Asian person, almost 30 percent of whites are 'not at all comfortable' regarding marriage to an African American.

Table 2 presents odds ratios from binary logistic regression models predicting whites' disapproval of their hypothetical daughter marrying an African American. Model 1 includes only the Christian nationalism measure without controls. The effect is statistically significant and the odds ratio $(\mathrm{OR}=1.09 ; p<.001)$ indicates that for every unit increase in the Christian nationalism scale (24 units), the likelihood that a white adult feels 'not at all comfortable' with her/his daughter marrying an African American increases by 9 percent. Model 2 includes the controls for religious tradition, biblical literalism, religious practice, and the respondent's desire for religious endogamy. The effect of Christian nationalism remains unchanged by the inclusion of the religion controls. For religious tradition, only those in "other" traditions differ significantly from evangelicals in their comfort with interracial marriage to blacks, but this effect washes out in other models. Biblical literalism is nonsignificant in its effect. Interestingly, religious practice is significantly and negatively associated with opposition to interracial marriage. Whites who more frequently attend worship service, pray, and read their sacred texts are actually less likely to express discomfort with interracial marriage. But paradoxically, whites who do not consider it important for their children to marry within their religion are also less likely to disapprove of interracial marriage. The robust nature of Christian nationalism's effect on whites' views toward interracial marriage in the face of these religious controls suggests that the observed effect of Christian nationalism is likely not due to theological conservatism, traditionalist affiliations, high religiosity, or whites' desire for religious endogamy.

Model 3 includes standard socio-demographic controls. Age and political conservatism are positively related to whites' discomfort with interracial marriage to African Americans, while 
being from the Eastern, Midwest, or Western United States (vs. being in the South) are negatively related to whites' disapproval of interracial marriage. With the inclusion of the sociodemographic controls, Christian nationalism, along with the other religion measures, has changed in relative size of its effect. Whereas Christian nationalism was the strongest effect in Model 2, the inclusion of the socio-demographic controls has dropped the substantive effect of Christian nationalism $(\beta=.21)$ to third, behind age $(\beta=.22)$ and political conservatism $(\beta=.26)$. Model 4 represents the full model and includes the measure for whether the respondent did not have any close black friends, which is also a strong predictor of whites' discomfort with interracial marriage. In the full model, the effect Christian nationalism on whites' intermarriage views is still significant beyond the .001 level and remains the third strongest predictor behind only age and political conservatism.

Tables 3 and 4 present the odds ratios from logistic regression models predicting whites' discomfort with their hypothetical daughter marrying a Latino or an Asian, respectively. The results from these analyses are largely the same as those in Table 2, but the effect of Christian nationalism is slightly weaker in both statistical and substantive significance. In the full models, Christian nationalism remains a significant predictor of whites' discomfort with intermarriage to Latinos or Asians, but now at the .05 level. And Christian nationalism is the fifth strongest predictor of whites' disapproval of interracial marriage to Latinos or Asians behind friendship with Latinos or Asians, political ideology, and living in the Midwest or West (versus the South).

In sum, these analyses demonstrate that white Americans who more strongly adhere to Christian nationalism tend to express greater discomfort with the idea of their daughter marrying anyone who is non-white, and especially African Americans. Thus, as social identity complexity 
decreases, the tendency toward intolerance of perceived out-groups increases. These findings strongly support our expectation.

\section{[TABLES 2 THROUGH 4 ABOUT HERE]}

Figure 1 presents predicted probabilities in order to illustrate the relationship between whites' discomfort with intermarriage to African Americans, Asians, and Latinos, across levels of support for Christian nationalism. As support for Christian nationalism increases, there is a steady increase in whites' discomfort with interracial marriage to all minority groups considered, and this increase is particularly sharp regarding African Americans. At the lowest levels of Christian nationalism, only about 10 percent of whites are 'not at all comfortable' with intermarriage to Asians or Latinos, and this rises to 25 percent of whites at the highest levels of Christian nationalism. By contrast, about 18 percent of whites are 'not at all comfortable with their daughters marrying an African American at the lowest levels of Christian nationalism, and this percentage vaults to almost 50 percent at the highest levels of Christian nationalism. The pattern observed in Figure 1 illustrates the general point that as social identity complexity decreases, in-groups bias is fortified and intolerance of out-groups increases. However, it is also clear that levels of intolerance directed toward out-groups varies by how the in-group perceives particular out-groups relative to others. This helps explain why Christian nationalism is both linked with opposition to marrying non-whites in general (because it fortifies notions of white purity and exclusivity), while being more strongly associated with opposition to marrying African Americans (who are seen as a more extreme and stigmatized out-group than Asians or Latinos).

[FIGURE 1 ABOUT HERE]

\section{Discussion and Conclusions}


What relevance does the convergence of national and religious identities have for the fortification of white racial boundaries in the United States? Guided by insights from social identity complexity theory, we argue that because of the complex and interconnected nature of social identities, the salience of certain identities (e.g., religion, national identity) may potentially diminish the willingness of group members to expand or relax in-group boundaries and for group members to consider racial out-groups as potential intimates, romantic partners, or family members. Using whites' views toward racial exogamy as an indicator of white racial boundaries, we anticipated that greater adherence to Christian nationalism would be associated with greater disapproval toward interracial marriage. Consistent with our expectations, our analyses affirm that greater adherence to Christian nationalism, signifying lower levels of social identity complexity, is strongly associated with whites' discomfort at the thought of their daughter marrying non-whites, and especially African Americans. This relationship exists even in the face of a variety of relevant religious, ideological and socio-demographic controls. Thus, our findings suggest that, for many white Americans, the idealized image of a Christian nation implies a nation where racial boundaries are fortified and white racial heritage is protected.

Before we further discuss the implications of this study, several limitations should be acknowledged. First, although white Americans' views toward interracial marriage represent a highly salient indicator of diminished social distance and whites' willingness to relax racial boundaries, it is admittedly only one indicator. Future research on this topic could employ other measures of white racial boundary-keeping (e.g., McDaniel et al. 2011), such as whites' views toward and participation in racially-diverse volunteer organizations, including places of worship, political action groups, and community-service associations, in which whites share ideological views and time with non-whites, developing solidarity and potentially transcending racial 
boundaries (see Marti, 2009). Second, although a number of recent studies have employed quantitative data to understand the delineation and defense of white racial boundaries (e.g., Edgell et al. 2006; Edgell and Tranby 2010; Hartmann et al. 2011), boundary-work is often profitably studied with qualitative data, such as in-depth interviews or ethnography (e.g., Emerson and Smith 2000; Lamont and Molnar 2000). More comprehensive assessments of the role of convergent social identities, and particularly white Christian nationalism, and their relationship with ethno-racial boundaries would ideally incorporate qualitative interviews to flesh out the mechanisms at play.

These limitations notwithstanding, our study extends the literature on religious nationalism in the United States, interracial romantic and family relationships, and social identity complexity theory. Fundamentally, our findings demonstrate a clear and near-linear association between adherence to Christian nationalism and whites' disapproval of white/non-white racial exogamy, even after controlling for political ideology, whites' desire for religious heritage, their friendships with non-white racial groups, and other socio-demographic factors. This central finding strongly suggests that movements on the Religious Right to protect or restore America's so-called Christian heritage are likely not devoid of racial content. The vast majority of Christian nationalists are white, and likely envision America's religious heritage through an AngloEuropean, Protestant lens (Edgell and Tranby 2010). Consequently, taken together with McDaniel et al. (2011) who found a strong link between Christian nationalism and whites' antiimmigrant sentiment, our study demonstrates that Christian nationalism contains a distinct ethnoracial component and suggest that white Christian nationalists' reported desire to either 'protect' or 'restore' America's 'Christian heritage' is laced with an implicit desire to maintain white supremacy and white racial purity (Aho 2013; Edgell and Tranby 2010; Goldberg 2006). 
Importantly, our results clarify that Christian nationalists are not merely politically conservative or desirous of religious exclusivity. If they were, controls for conservative political ideology and desire for religious endogamy in the multivariate models would render the Christian nationalism measure non-significant. Rather, Christian nationalism influences white Americans' defense of racial boundaries, and in this case their discomfort with interracial marriage, above and beyond the effects of political conservatism and religious exclusivity separately. Figure 2 illustrates this relationship. Figure 2A displays the effects of Christian nationalism on the predicted probabilities of discomfort with one's daughter marrying an African American across different political ideologies. Regardless of political ideology, Christian nationalists are more likely to express disapproval toward interracial marriage. So too, Figure 2B shows the relationship between Christian nationalism and the predicted probabilities of discomfort with marrying an African American by whether the respondent considers it important for their children to marry within their faith or not. Here again Christian nationalists are more likely to oppose racial endogamy regardless of their desire for religious endogamy.

\section{[FIGURE 2 ABOUT HERE]}

Our analyses also provide further support for the utility of the theoretical construct of social identity complexity. Extending prior research on SIC and attitudes toward immigrant outgroups, our findings show that varying levels of SIC dramatically influence views of more intimate relationships like interracial marriage (see Figures 1 and 2). This study also highlights the methodological flexibility of social identity complexity. The majority of prior SIC research relied on convenience samples of college students or respondents living near the researchers. The current analysis demonstrates that measures of SIC can be created using national, random data and usefully applied in the analysis of broad attitudes (see McDaniel et al. 2011). As SIC 
predicts, individuals who tend towards a single convergent social identity like Christian nationalism are much more likely to erect strict boundaries between in-groups and out-groups. The interconnectedness of racial, national, and religious identities for many white Americans serves to fortify in-group boundaries and ultimately limit their openness to intimate cross-race relations like interracial marriage. Future research, particularly quantitative studies using large, national datasets, should continue to utilize social identity complexity to examine how individual perceptions of collective identities shape racial attitudes.

In conclusion, some researchers question a link between intolerance and beliefs about the 'Christian' heritage of the United States. In Christian America? (2000), Smith points out that while many evangelicals maintain beliefs about a Christian America, very few actually oppose pluralism. He posits that adherence to a belief that the U.S. is a Christian nation is, basically, an effort to maintain a collective identity. Therefore, it has little to do with intolerance or rejecting pluralism in its various forms (Merino 2010). Our findings contradict this interpretation, however. For white Americans, Christian nationalism is strongly associated with racial intolerance. While Christian nationalist beliefs may provide a collective identity, social identity complexity theory highlights how it is through such single, convergent, collective identities that intolerance is propagated. It is important for future research to continue to examine Christian nationalism and document when and how it is associated with various other forms of intolerance. 


\section{References:}

Aho, James. 2013. "Christian Heroism and the Reconstruction of America." Critical Sociology 39:545-60.

Allport, Gordon. 1954. The Nature of Prejudice. Reading: Addison-Wesley.

Bader, Christopher, Carson Mencken, and Paul Froese. 2007. "American Piety 2005:

Content and Methods of the Baylor Religion Survey." Journal for the Scientific Study of Religion 46:447-463.

Barkun, Michael. 1994. Religion and the Racist Right: The Origins of the Christian Identity Movement. Chapel Hill: University of North Carolina Press.

Barton, David. 2011. “The Founding Fathers and Slavery.” Retrieved on August 8, 2013 (http://www.wallbuilders.com/libissuesarticles.asp?id=122).

Bonilla-Silva, Eduardo. 1999. The Essential Social Fact of Race. American Sociological Review 64:899-906.

Brewer, Marilynn, Karen Gonsalkorale, and Andrea van Dommelen. 2013. "Social Identity Complexity: Comparing Majority and Minority Ethnic Group Members in a Multicultural Society." Group Processes and Intergroup Relations 16:529-44.

Brewer, Marilynn, and Kathleen Pierce. 2005. "Social Identity Complexity and Outgroup Tolerance." Personality and Social Psychology Bulletin 31:428-37.

Childs, Erica. 2005. Navigating Interracial Borders: Black-White Couples and Their Social Worlds. New Brunswick: Rutgers University Press.

Edgell, Penny, Joseph Gerteis, and Douglas Hartmann. 2006. Atheists as "Other": Moral Boundaries and Cultural Membership in American Society. American Sociological Review 71:211-34. 
Edgell, Penny, and Eric Tranby. 2010. "Shared Visions? Diversity and Cultural Membership in American Life.” Social Problems 57:175-204.

Emerson, Michael, and Christian Smith. 2000. Divided by Faith: Evangelical Religion and the Problem of Race in America. New York: Oxford University Press.

Goldberg, Michelle. 2006. Kingdom Coming: The Rise of Christian Nationalism. New York: Norton.

Golebiowska, Ewa. 2007. The Contours and Etiology of Whites' Attitudes toward BlackWhite Interracial Marriage. Journal of Black Studies 38:268-287.

Gordon, Milton. 1964. Assimilation in American life. New York: Oxford University Press.

Gorski, Philip. 2009. “Conservative Protestantism in the United States: Toward a Comparative Historical Perspective.” In Evangelicals and Democracy in America, vol. 1, edited by S. Brint, and J. Schroedel, 74-114. New York: Russell Sage.

Gorski, Philip. 2010. “Civil Religion Today. Association of Religion Data Archives Guiding Papers Series.” Retrieved August 1, 2013 (http://www.palsresearch.org/rrh/papers/guidingpapers/Gorski.pdf).

Hartmann, Douglass, Daniel Winchester, Penny Edgell, Joseph Gerteis. 2011. "How Americans Understand Racial and Religious Differences: A Test Of Parallel Items From A National Survey." The Sociological Quarterly 52:323-45.

Herman, Melissa R. Mary E. Campbell. 2012. “I Wouldn’t, but You Can: Attitudes Toward Interracial Relationships.” Social Science Research 41:343-58.

Johnson, Bryan, and Cardell Jacobson. 2005. Contact in Context: An Examination of Social Settings on Whites' Attitudes toward Interracial Marriage. Social Psychology Quarterly 68:387-399. 
Lamont, Michele and Virag Molnar. 2002. "The Study of Boundaries in the Social Sciences." Annual Review of Sociology 28:167-95.

Lee, Jennifer, and Frank Bean. 2010. The Diversity Paradox: Immigration and the Color Line in Twenty-first Century America. New York: Russell Sage.

Marti, Gerardo. 2009. “Affinity, Identity, and Transcendence: The Experience of Religious Racial Integration in Diverse Congregations.” Journal for the Scientific Study of Religion 48:53-68.

McDaniel, Eric L., Irfan Nooruddin, Allyson Faith Shortle. 2011. "Divine Boundaries: How Religion Shapes Citizens Attitudes toward Immigrants.” American Politics Research 39: 205-233.

Merino, Stephen. 2010. “Religious Diversity in a 'Christian Nation': The Effects of Theological Exclusivity and Interreligious Contact on the Acceptance of Religious Diversity." Journal for the Scientific Study of Religion 49:231-46.

Miller, Kevin, Marilynn Brewer, Nathan Arbuckle. 2009. "Social Identity Complexity: Its Correlates and Antecedents." Group Processes and Intergroup Relations 12:79-94.

Omi, Michael, Winant, Howard. 1994. Racial Formation in the United States: From the 1960s to the 1990s. New York: Routledge.

Pampel, Fred. 2000. Logistic Regression: A Primer. Thousand Oaks: Sage.

Pascoe, Peggy. 2009. What Comes Naturally: Miscegenation Law and The Making of Race in America. New York: Oxford University Press.

Putnam, Robert, and David Campbell. 2010. American Grace: How Religion Divides and Unites Us. New York: Simon \& Schuster.

Qian, Zenchao, and Daniel Lichter. 2007. "Social Boundaries and Marital Assimilation: 
Interpreting Trends in Racial and Interethnic Marriage.” American Sociological Review 72:68-94.

Roccas, Sonia, and Marilynn Brewer. 2002. "Social Identity Complexity.” Personality and Social Psychology Review 6:88-106.

Root, Maria. 2001. Love’s Revolution: Interracial Marriage. Philadelphia: Temple University Press.

Rosenfeld, Michael J. 2007. The Age of Independence: Interracial Unions, Same-Sex Unions, and the Changing American Family. Cambridge: Harvard University Press.

Rubin, Donald. 1996. "Multiple Imputation after 18+ Years.” Journal of the American Statistical Association 91:473-89.

Schmid, Katharina, Miles Hewstone, Nicole Tausch, Ed Cairns, Joanne Hughes. 2009. “Antecedents and Consequences of Social Identity Complexity: Intergroup Contact, Distinctiveness Threat, and Outgroup Attitudes.” Personality and Social Psychology Bulletin 35:1085-98.

Smith, Christian. 2000. Christian America? What Evangelicals really Want. Berkeley: University of California Press.

Spickard, Paul. 1989. Mixed Blood: Intermarriage and Ethnic Identity in Twentieth-Century America. Madison: University of Wisconsin Press.

Steensland, Brian, Jerry Z. Park., Mark Regnerus, Lynn Robinson, W. Bradford Wilcox, Robert Woodberry. 2000. “The Measure of American Religion: Toward Improving The State of the Art." Social Forces 79:291-318.

Wilson, Deborah, and Cardell Jacobson. 1995. Whites Attitudes towards Black and White 
Interracial Marriage. In American Families: Issues in Race and Ethnicity, edited by Cardell Jacobson, 353-67. New York: Garland.

Yancey, George. 1999. “An Examination of The Effects of Residential and Church Integration On Racial Attitudes of Whites." Sociological Perspectives 42:279-304.

Yancey, George. 2001. "Racial Attitudes: Differences in Racial Attitudes of People Attending Multiracial and Uniracial Congregations." In Research in the Social Scientific Study of Religion, edited by D. Moberg and R. Peidmont, 185-206. Leiden: Brill.

Yancey, George. 2007. "Homogamy over the Net: Using Internet Advertisements to Discover Who Interracially Dates." Journal of Social and Personal Relationships 24:913-930. 
Table 1: Descriptive and Bivariate Statistics for Whites Only (MI Data)

\begin{tabular}{|c|c|c|c|}
\hline Variable & Description & Mean or \% & SD \\
\hline $\begin{array}{l}\text { Daughter Marry African } \\
\text { American }\end{array}$ & $1=$ Not at all comfortable & $29.8 \%$ & --- \\
\hline $\begin{array}{l}\text { Daughter Marry } \\
\text { Hispanic/Latino }\end{array}$ & $1=$ Not at all comfortable & $19.7 \%$ & --- \\
\hline Daughter Marry Asian & $1=$ Not at all comfortable & $19.8 \%$ & --- \\
\hline $\begin{array}{l}\text { U.S. is a Christian } \\
\text { Nation }(\alpha=0.87)\end{array}$ & $\begin{array}{l}\text { Summed index, } 6=\text { Strongly disagree } \\
\text { to } 30=\text { Strongly agree }\end{array}$ & 17.97 & 6.44 \\
\hline Age & Age in years, 18 to 96 & 51.17 & 16.48 \\
\hline Female & $1=$ Female & $55.5 \%$ & --- \\
\hline Married & $1=$ Married & $67.8 \%$ & --- \\
\hline Children & $1=$ Has at least one child & $74.4 \%$ & --- \\
\hline Income & $\begin{array}{l}1=\$ 10,000 \text { or less to } 7=\$ 150,000 \text { or } \\
\text { more }\end{array}$ & 4.46 & 1.53 \\
\hline Education & $\begin{array}{l}1=8^{\text {th }} \text { grade or less, } 7=\text { postgraduate } \\
\text { work } / \text { degree }\end{array}$ & 4.67 & 1.62 \\
\hline East & $1=$ East & $22.0 \%$ & --- \\
\hline Midwest & $1=$ Midwest & $24.1 \%$ & --- \\
\hline South & $1=$ South & $30.0 \%$ & --- \\
\hline West & $1=$ West & $23.9 \%$ & --- \\
\hline Politically Conservative & $1=$ Liberal to $7=$ Conservative & 4.32 & 1.61 \\
\hline No Religious Endogamy & $\begin{array}{l}1=\text { Not important at all that children } \\
\text { marry someone with same religion as } \\
\text { respondent }\end{array}$ & $22.6 \%$ & --- \\
\hline Biblical Literalist & $1=$ Biblical literalist & $19.9 \%$ & --- \\
\hline $\begin{array}{l}\text { Religious Practice Index } \\
(\alpha=0.84)\end{array}$ & $\begin{array}{l}\text { Standardized and summed index }-4.12 \\
=\text { least involved to } 4.17=\text { most } \\
\text { involved }\end{array}$ & -0.06 & 2.60 \\
\hline Evangelical Protestant & $1=$ Evangelical Protestant & $31.1 \%$ & --- \\
\hline Mainline Protestant & 1 = Mainline Protestant & $23.0 \%$ & --- \\
\hline Catholic & $1=$ Catholic & $23.7 \%$ & --- \\
\hline Jewish & 1 = Jewish & $2.3 \%$ & --- \\
\hline Other & $1=$ Other & $6.3 \%$ & --- \\
\hline No Religion & $1=$ No Religion & $11.4 \%$ & --- \\
\hline $\begin{array}{l}\text { No close African } \\
\text { American friends }\end{array}$ & $1=$ None & $29.7 \%$ & --- \\
\hline $\begin{array}{l}\text { No close } \\
\text { Hispanic/Latino friends }\end{array}$ & $1=$ None & $36.8 \%$ & --- \\
\hline No close Asian friends & $1=$ None & $50.0 \%$ & --- \\
\hline
\end{tabular}

Source: BRS (2007) 
Table 2: Logistic Regression Analysis of White Respondents Being “Not At All Comfortable" with Daughter's Interracial Marriage to an African American Individual (MI Data)

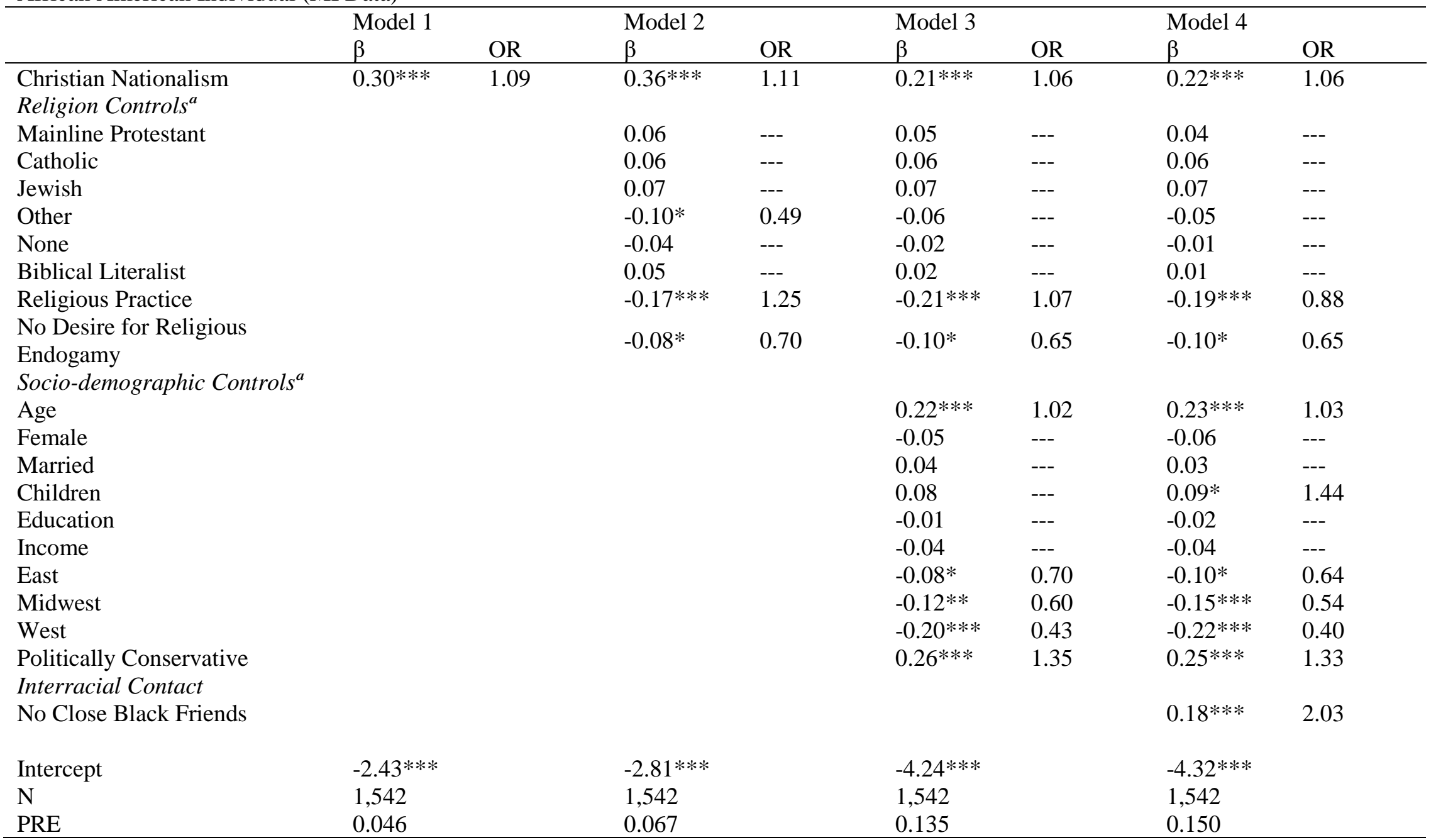

$* \mathrm{p}<.05 ; * * \mathrm{p}<.01 ; * * * \mathrm{p}<.001$

$\beta=$ Standardized Coefficient OR $=$ Odds Ratio

PRE = Proportional Reduction in Error (Likelihood Ratio/-2 Log Likelihood)

${ }^{a}$ Evangelical Protestant and South are the contrast categories 
Table 3: Logistic Regression Analysis of White Respondents Being "Not At All Comfortable" with Daughter's Interracial Marriage to a Hispanic/Latino Individual (MI Data)

\begin{tabular}{|c|c|c|c|c|c|c|c|c|}
\hline & \multicolumn{2}{|l|}{ Model 1} & \multicolumn{2}{|l|}{ Model 2} & \multicolumn{2}{|l|}{ Model 3} & \multicolumn{2}{|l|}{ Model 4} \\
\hline & $\beta$ & OR & $\beta$ & OR & $\beta$ & OR & $\beta$ & OR \\
\hline Christian Nationalism & $0.27 * * *$ & 1.08 & $0.30 * * *$ & 1.09 & $0.15 *$ & 1.04 & $0.15^{*}$ & 1.04 \\
\hline \multicolumn{9}{|l|}{ Religion Controls ${ }^{a}$} \\
\hline Mainline Protestant & & & 0.05 & --- & 0.06 & --- & 0.06 & --- \\
\hline Catholic & & & -0.02 & --- & -0.00 & --- & 0.02 & --- \\
\hline Jewish & & & 0.05 & --- & 0.07 & --- & 0.07 & --- \\
\hline Other & & & -0.10 & --- & -0.06 & --- & -0.04 & --- \\
\hline None & & & -0.03 & --- & -0.01 & --- & -0.01 & --- \\
\hline Biblical Literalist & & & $0.10 *$ & 1.60 & 0.07 & --- & 0.06 & --- \\
\hline Religious Practice & & & $-0.19 * * *$ & 0.88 & $-0.18 * *$ & 0.88 & $-0.15 * *$ & 0.90 \\
\hline No Desire for Religious Endogamy & & & -0.08 & 0.69 & $-0.09 *$ & 0.67 & -0.09 & --- \\
\hline \multicolumn{9}{|l|}{ Socio-demographic Controls ${ }^{a}$} \\
\hline Age & & & & & $0.12 * *$ & 1.01 & $0.10 *$ & 1.01 \\
\hline Female & & & & & -0.07 & --- & $-0.09 *$ & 0.72 \\
\hline Married & & & & & 0.05 & --- & 0.03 & --- \\
\hline Children & & & & & 0.03 & --- & 0.06 & --- \\
\hline Education & & & & & $-0.10 *$ & 0.89 & $-0.12 *$ & 0.88 \\
\hline Income & & & & & -0.08 & --- & -0.07 & --- \\
\hline East & & & & & $-0.11 *$ & 0.61 & $-0.14 * *$ & 0.54 \\
\hline Midwest & & & & & $-0.18 * * *$ & 0.46 & $-0.21 * * *$ & 0.41 \\
\hline West & & & & & $-0.23 * * *$ & 0.38 & $-0.17 * *$ & 0.48 \\
\hline Politically Conservative & & & & & $0.19 * * *$ & 1.24 & $0.19 * * *$ & 1.24 \\
\hline \multicolumn{9}{|l|}{ Interracial Contact } \\
\hline No Close Hispanic/Latino Friends & & & & & & & $0.28 * * *$ & 2.87 \\
\hline Intercept & $-2.84 * * *$ & & -3.02 & & $-2.63 * * *$ & & $-2.97 * * *$ & \\
\hline $\mathrm{N}$ & 1,542 & & 1,542 & & 1,542 & & 1,542 & \\
\hline PRE & 0.034 & & 0.055 & & 0.109 & & 0.144 & \\
\hline
\end{tabular}

$* \mathrm{p}<.05 ; * * \mathrm{p}<.01 ; * * * \mathrm{p}<.001$

$\beta=$ Standardized Coefficient; OR = Odds Ratio

PRE = Proportional Reduction in Error (Likelihood Ratio/-2 Log Likelihood)

${ }^{a}$ Evangelical Protestant and South are the contrast categories 
Table 4: Logistic Regression Analysis of White Respondents Being "Not At All Comfortable” with Daughter's Interracial Marriage to an Asian Individual (MI Data)

\begin{tabular}{|c|c|c|c|c|c|c|c|c|}
\hline & \multicolumn{2}{|l|}{ Model 1} & \multicolumn{2}{|l|}{ Model 2} & \multicolumn{2}{|l|}{ Model 3} & \multicolumn{2}{|l|}{ Model 4} \\
\hline & $\beta$ & OR & $\beta$ & OR & $\beta$ & OR & $\beta$ & OR \\
\hline Christian Nationalism & $0.29 * * *$ & 1.09 & $0.31 * * *$ & 1.09 & $0.18 * *$ & 1.05 & $0.16^{*}$ & 1.05 \\
\hline \multicolumn{9}{|l|}{ Religion Controls ${ }^{a}$} \\
\hline Mainline Protestant & & & $0.11 *$ & 1.59 & $0.12 *$ & 1.66 & $0.12 *$ & 1.65 \\
\hline Catholic & & & 0.05 & --- & 0.06 & --- & 0.06 & --- \\
\hline Jewish & & & $0.09 *$ & 3.12 & $0.11 * *$ & 4.04 & $0.12 * *$ & 4.13 \\
\hline Other & & & $-0.17 *$ & 0.29 & -0.11 & --- & -0.11 & --- \\
\hline None & & & -0.03 & --- & 0.00 & --- & 0.01 & --- \\
\hline Biblical Literalist & & & $0.14 * *$ & 1.89 & $0.11 *$ & 1.62 & $0.11 *$ & 1.63 \\
\hline Religious Practice & & & $-0.17 * *$ & 0.89 & $-0.18 * *$ & 0.89 & $-0.16^{*}$ & 0.90 \\
\hline No Desire for Religious Endogamy & & & -0.09 & --- & $-0.11 *$ & 0.61 & $-0.12 *$ & 0.60 \\
\hline \multicolumn{9}{|l|}{ Socio-demographic Controls ${ }^{a}$} \\
\hline Age & & & & & $0.14 * * *$ & 1.02 & $0.14 * * *$ & 1.02 \\
\hline Female & & & & & -0.04 & --- & -0.04 & --- \\
\hline Married & & & & & 0.00 & --- & -0.02 & --- \\
\hline Children & & & & & 0.09 & --- & $0.10 *$ & 1.54 \\
\hline Education & & & & & $-0.14 * *$ & 0.86 & $-0.14 * *$ & 0.86 \\
\hline Income & & & & & -0.02 & --- & 0.00 & --- \\
\hline East & & & & & $-0.12 *$ & 0.60 & $-0.11^{*}$ & 0.62 \\
\hline Midwest & & & & & $-0.18 * * *$ & 0.47 & $-0.17 * * *$ & 0.49 \\
\hline West & & & & & $-0.25 * * *$ & 0.35 & $-0.20 * * *$ & 0.42 \\
\hline Politically Conservative & & & & & $0.17 * *$ & 1.21 & $0.17 * *$ & 1.21 \\
\hline \multicolumn{9}{|l|}{ Interracial Contact } \\
\hline No Close Asian Friends & & & & & & & $0.21 * * *$ & 2.13 \\
\hline Intercept & $-2.96 * * *$ & & $-3.27 * * *$ & & $-3.18 * * *$ & & -3.73 & \\
\hline $\mathrm{N}$ & 1,542 & & 1,542 & & 1,542 & & 1,542 & \\
\hline PRE & 0.040 & & 0.073 & & 0.130 & & 0.147 & \\
\hline
\end{tabular}

$* \mathrm{p}<.05 ; * * \mathrm{p}<.01 ; * * * \mathrm{p}<.001$

$\beta=$ Standardized Coefficient; OR = Odds Ratio

PRE = Proportional Reduction in Error (Likelihood Ratio/-2 Log Likelihood)

${ }^{\text {a}}$ Evangelical Protestant and South are the contrast categories. 
Figure 1: Predicted Probabilities of Whites Being "Not at All Comfortable" with Daughter Marrying Interracially (MI Data)

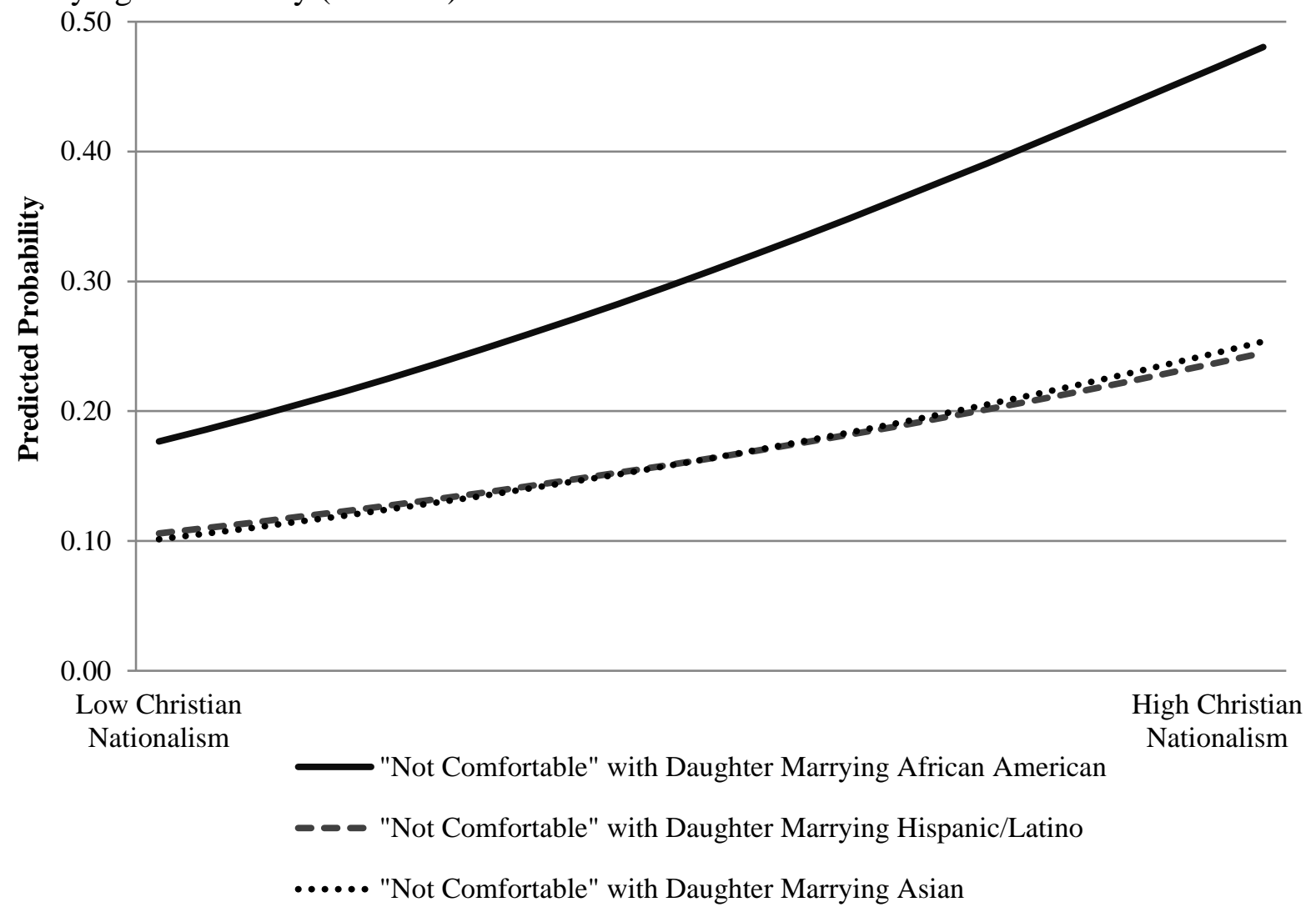


Figure 2: Predicted Probabilities of Whites Being "Not At All Comfortable" with Daughter Marrying an African-American by Christian Nationalism and...

2A. Political Ideology

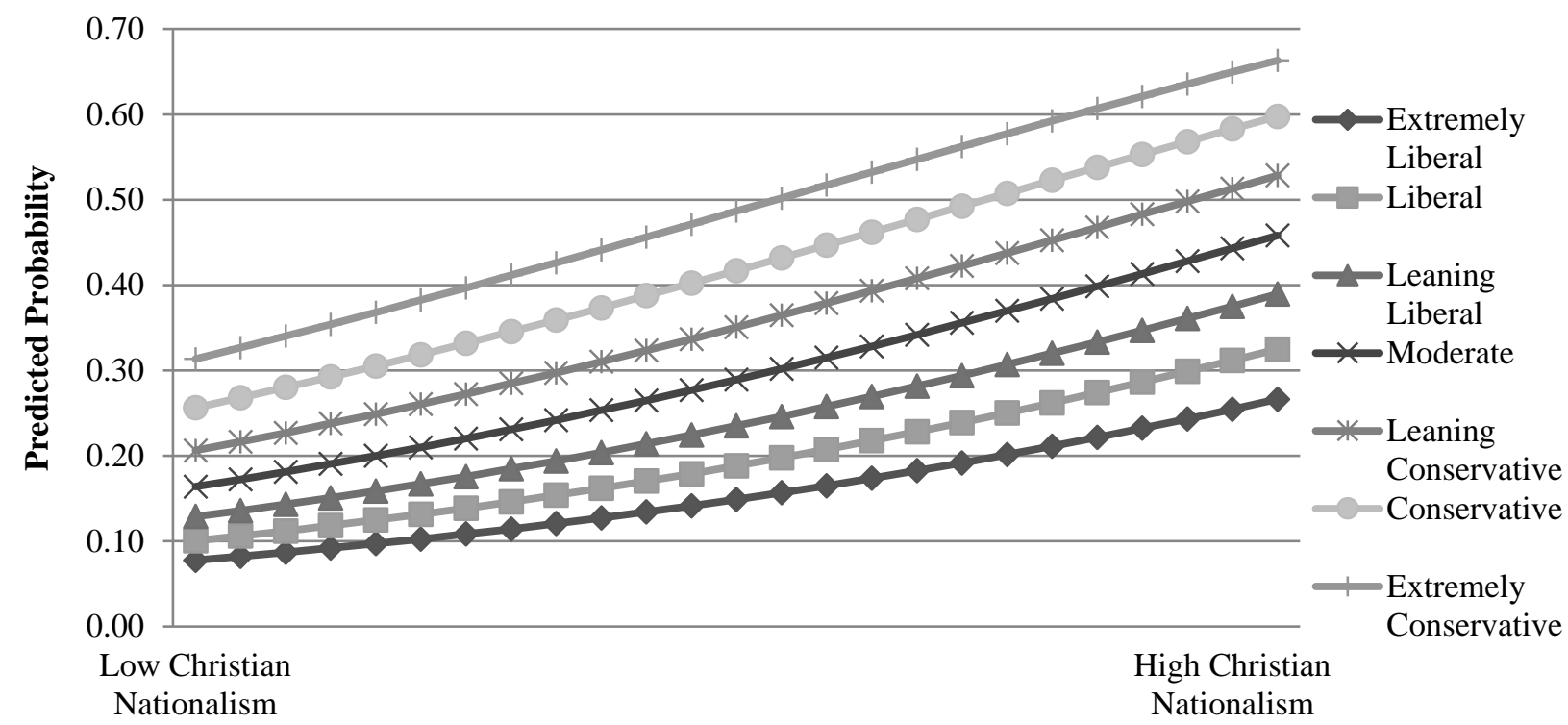

2B. Desire for Religious Endogamy

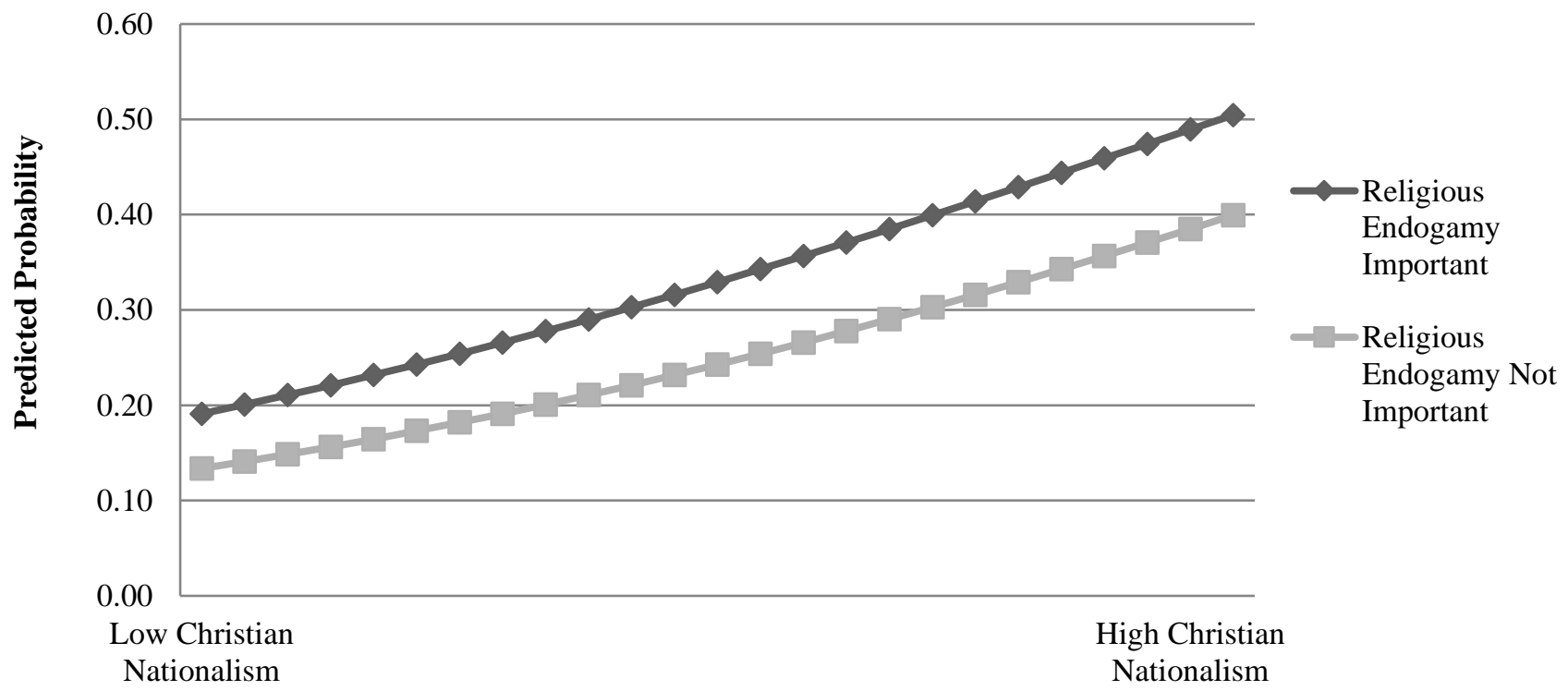

